\title{
The neo-regulation of internet platforms in the United Kingdom
}

\section{Philip Schlesinger ()}

CCPR and CREATe, University of Glasgow, Glasgow, Scotland, United Kingdom of Great Britain and Northern Ireland

\section{Correspondence}

Philip Schlesinger, CCPR and CREATe, University of Glasgow, 13 Professors' Sq, University Ave, Glasgow G12 8QH,

Scotland, United Kingdom of Great Britain and Northern Ireland.

Email: Philip.Schlesinger@glasgow.ac.uk

\section{Funding information}

Arts and Humanities Research Council, Grant/Award Number: AH/S001298/1

\begin{abstract}
In 2020, a new platform-regulatory model was initiated in the United Kingdom. The main focus of this article is on the development of the Digital Regulators Cooperation Forum (DRCF), set up to regulate the continually changing challenges posed by major platforms. The British model has drawn on UK competition regulation, collegial governance of international banking, and international 'agile' regulation debates. The backdrop to this 'neo-regulatory' development has been Brexit (the UK's withdrawal from the European Union). In late 2021, for the first time, the DRCF became a serious focus of parliamentary scrutiny, with recommendations for reform. Assessment of its effectiveness now largely awaits the enactment of statutory powers by the UK Parliament regarding first, 'online harms', and second, the use of pro-competitive regulation in digital markets. Whether the DRCF's model will have exemplary appeal beyond the United Kingdom is an open question.
\end{abstract}

\section{KE Y WORDS}

Brexit, Digital Regulators Cooperation Forum, European Union, Global Britain, online harms, platform neo-regulation, pro-competition

\section{INTRODUCTION}

This article analyses the current restructuring of platform regulation in the United Kingdom in response to the multifold challenges posed by major platforms. The British policy agenda and regulatory response are presently encapsulated in two portmanteau rallying points: remedying 'online harms' (which mainly encompass social and political issues) and pursuing 
a 'pro-competition' approach (by addressing malfunctioning markets to promote consumer interests and business innovation). In the near future, the UK Parliament will pass relevant statutes. The scope of the Online Safety Bill is in debate at this time of writing, early in 2022, whereas further legislation is also anticipated on competition in digital markets.

This agenda has crystallised during the geopolitical reorientation of the British state, which has been driven by Brexit, the UK's formal withdrawal from the European Union (EU) on 31 December 2020, following the June 2016 referendum on EU membership. A profound constitutional rupture, therefore, has influenced how British regulators have reconceived their roles and agendas.

As in the United Kingdom, interventionist approaches in many states have resulted in legislative and administrative measures taken to address the far-reaching impact of major global platforms. Big Tech's market power, as well as its wider political and social impacts, have driven the contemporary 'techlash' (Faroohar, 2018) and are at the heart of its 'digital dominance' (Moore \& Tambini, 2018). In an overview, Flew (2021, ch. 3) has usefully identified major issues now in contention. These include privacy, security and safety; online disinformation and 'fake news'; data rights and protections; the governance of algorithms; hate speech and online abuses; platforms' information dominance and adverse competitive impacts on the media and creative economies.

Although British regulatory innovation undoubtedly has specific national characteristics, the UK's policy agenda is not unique. It has aligned with an international consensus that ' $e x$ ante regulation is needed to address the market dominance of the very largest digital platforms' (Schnitzer et al., 2021, p. 1), which has meant designating the key actors that require regulation.

Late in 2020, for instance, the EU introduced two key legislative measures. The Digital Markets Act (DMA), focused on 'large systemic online platforms' with a 'gatekeeper' role, namely those operating as key intermediaries between businesses and users in digital markets. The DMA requires an economic assessment of platforms with a significant impact on the internal market across multiple EU countries. The Digital Services Act complements the DMA, and is concerned with risks posed by 'very large online platforms' that reach more than $10 \%$ of EU consumers. The goal is to counteract major online intermediaries' dissemination of illegal content and their infliction of societal harms (European Commission [EC], 2021a, 2021b).

Furthermore, there has been considerable debate about antitrust measures in the United States. Khan (2018, p. 122), in an influential analysis of Amazon, discussed how 'business strategies and current market dominance pose anticompetitive concerns that the consumer welfare framework in antitrust fails to recognise'. In 2020, an antitrust suit was initiated against Facebook to reverse the acquisitions of Instagram and WhatsApp, with another against Google regarding its dominance of internet search. The Stigler Committee on Digital Platforms' (2019) analysis of markets in which digital platforms tend to monopolisation has argued for stringent regulation of potentially anticompetitive mergers and proposed the creation of a cross-sector Digital Authority. The US debate achieved initial legislative momentum when the House of Representatives, in June 2021, introduced a package of antitrust bills, some including structural remedies, to address the performance of 'covered platform operators' (Schnitzer et al., 2021).

In Australia, ahead of the United Kingdom, both competition and online harms issues have been addressed legislatively. In March 2021, following a failed attempt to establish a voluntary code, and Facebook's subsequent 'black-out' of Australian news sites, a Mandatory News Media Bargaining Code was enacted to ensure that news businesses receive revenues from digital platforms that distribute their content (Flew, 2021). The Online Safety Act, setting out Basic Online Safety Expectations for service providers, was passed by the Australian parliament in June 2021 (eSafety Commissioner, 2021). 
British regulatory practice, therefore, has developed in an international context that provides pertinent models, allies and, sometimes, key personnel. The Organisation for Economic Co-operation and Development (OECD), an intergovernmental organisation focused on the economy and world trade, is a case in point. The OECD advocates 'agile regulatory governance to harness innovation', given digitalisation's challenge to national jurisdictional boundaries (OECD, 2021a). Likewise, the World Economic Forum (WEF, 2018, 2020), a non-governmental, agenda-setting global business lobby, calls for transformed governance structures and policy-making models and also espouses 'agile governance'. Both bodies' thinking, applicable to digital platforms, has been influential in the United Kingdom, which in November 2020 became a signatory of the OECD's Agile Nations Charter (HM Government, 2019, 2020).

For Flew (2021), present international trends represent a widespread drive towards what he terms a 'regulated internet'. It is argued here that the present British attempt to regulate platform power, which is still in its infancy, warrants a more precise and specific designation than this to signal its potential novelty and scope. A neo-regulatory phase has begun, marked by initial steps taken in rethinking the requisite organisational framework.

This contention may be given greater precision. First, the geopolitics of Brexit has spurred on the anticipatory repositioning of regulatory policy. Although this is a case-specific matter, taking geopolitics as a relevant starting point for other jurisdictions' regulatory policy developments might be productive. Second, the increasingly formalised collaboration of key UK digital regulators has engendered an emergent model designed for a continually changing landscape. It is aligned with the OECD's (2021b, 2021c) advocacy of a 'whole-ofgovernment' and 'one-stop-shop' approach, intended both to facilitate regulatory coordination and make regulators more accessible to business and government. Third, a British regulatory preference for the use of codes practice or conduct is apparent, which is congruent with the WEF's (2018) 'soft law' approach, raising questions about rigorous enforcement. This distinct configuration has not previously been studied and, as will be seen, in late 2021 began to achieve political visibility, focusing concerns about both its governance and effectiveness.

\section{BREXIT AND 'GLOBAL BRITAIN'}

The UK Conservative government's Integrated Review of a 'Global Britain', launched In March 2021, proclaimed:

A more integrated approach supports faster decision-making, more effective policy-making and more coherent implementation by bringing together defence, diplomacy, development, intelligence and security, trade and aspects of domestic policy in pursuit of cross-government, national objectives (HM Government, 2021, p. 18).

This calibration of global geopolitics conceives the United Kingdom as a national security state facing serious adversaries and requiring a 'whole-of-society approach to resilience' (HM Government, 2021, p. 21). In political and expert circles, doubts figure about how integrated the UK policy machine actually is: whether sufficient oversight of national security exists and if the critical national infrastructure is adequately safeguarded. Despite such reservations, global-British ideology should be taken seriously in the field of platform regulation because its consequences are increasingly evident. ${ }^{2}$

The UK's defence of critical national infrastructure is high on the agenda (HM Government, 2021, p. 10, 77). As Mueller (2017) notes, the social penetration of digital technology 
makes cyber security fundamental to national security. In January 2020, the National Cyber Security Centre (NCSC) identified Huawei as a 'high-risk vendor' for the planned 5G cellular network upgrade. The government decided to remove Huawei from UK telecoms networks by 2027 because 'national dependence' on a risky supplier constituted a 'significant security risk' (NCSC, 2020, p. 5, 13). This was a relatively minor move in the grand geopolitical struggle between the United States and China over competitive innovation and global market dominance (O'Hara \& Hall, 2021, ch. 12). The government concluded that since ' $[\mathrm{t}$ ] he geopolitical role of non-state actors, in particular large tech companies, is likely to continue to grow', legislation on 'online harms' was required (HM Government, 2021, p. 26). It also stressed the role of active 'regulatory diplomacy to influence the rules, norms and standards governing technology and the digital economy' (HM Government, 2021, p. 20). The United Kingdom's 'soft power' ambitions (Nye, 1990) include exercising international 'convening power'.

The global-British 'vision' is Manichaean, with the world seen as an 'increasingly contested domain' between 'digital freedom' and 'digital authoritarianism'. This contraposition of 'open societies' to 'autocracies' starkly echoes Cold War thinking. In the Integrated Review, concern about China as a 'systemic competitor' is a key determinant of the UK's post-Brexit 'Indo-Pacific' turn. ${ }^{3}$ In Europe, Russia is fingered as 'the most acute direct threat to the UK' (HM Government, 2021, p. 21). ${ }^{4}$

Sundered from the EU, the United Kingdom is grandiosely self-cast as a unique 'European country with global interests' intent on redefining its role (HM Government, 2021, p. 59). The Aukus defence pact announced on 15 September 2021 between Australia, the United Kingdom and the United States-aimed at China's containment-typifies Britain's new search for tailored alliances.

\section{THE VOGUE FOR CONCURRENT REGULATION}

British neo-regulatory know-how has been reorganised into an open-ended expert consortium, with the national platform-regulatory space (Hancher \& Moran, 1998) incrementally redefined in response to the issues in play. 'Concurrency' of this kind first developed in the United Kingdom during the 1980s privatisation of major public enterprises. The modus operandi was updated in the Enterprise and Regulatory Reform Act 2013 (ERRA) (Dunne, 2021, p. 258). Another influence came from the EU where, in response to the 2008 banking crisis, a 'college' model was established in 2009 :

Colleges of supervisors can be defined as permanent, although flexible, structures for cooperation and coordination among the authorities responsible for and involved in the supervision of the different components of cross-border banking institutions (CEBS, 2010, p.3).

The UK Turner Review endorsed the 'effective operation of colleges of supervisors for the largest complex and cross-border financial institutions' (FSA, 2009, p. 9). The collegial model is used in British financial regulation (Financial Services Regulator Initiatives Forum, 2021). Banking and financial services have influenced present developments in British digital platform regulation, as has the OECD's (2021c) advocacy of a regulatory 'onestop-shop'.

The model foregone by using a forum or college is that of a 'converged' regulator: an integrated single authority deploying multidisciplinary expertise. An agency of this kind is presently not on the cards, although an increasingly integrated form of concurrency is. 


\section{FIRST STRAWS IN THE WIND}

In January 2017, the UK Cabinet Office published a Regulatory Futures Review (Cabinet Office, 2017), which recommended data sharing, coordinated intelligence sharing, broadening regulatory knowledge and expertise, and setting up core training courses (Cabinet Office, 2017, p. 4, 7).

Greg Clark MP, Conservative Secretary of State from July 2016 to July 2019 in the Department for Business, Energy and Industrial Strategy (BEIS) engaged in regulatory activism. BEIS's strategy, premised on leaving the EU, was encapsulated in its White Paper of June 2019 (BEIS, 2019). Technological development, it argued, had engendered a 'fourth industrial revolution' requiring appropriate governance structures and policy models. This aligned with the WEF's (2018) advocacy of 'agile governance' and adopted its lexicon. The WEF recommended prioritising regulatory outcomes rather than sticking to prescriptive rules as well as an expanded role for stakeholders-especially business innovators-as codesigners of an updated 'governance ecosystem'. If adopted, the state's regulatory role would reduce in a multistakeholder system featuring 'agile' industrial self-regulation.

The White Paper (BEIS, 2019, p. 17) undertook to 'create an outcome-focused, flexible regulatory system that enables innovation to thrive', offering 'clarity for business through better use of regulatory guidance, codes of practice and industrial standards'. BEIS' regulatory machinery includes its Better Regulation Executive, which issues crossdepartmental guidance on impact assessments and post-implementation reviews (BEIS, 2020). Strategic thinking draws on arm's-length expert groups: the Regulatory Policy Committee scrutinises how regulatory change affects businesses (BEIS, 2019), and has been complemented by a Regulatory Horizons Council, focused on facilitating technological innovation (BEIS, 2020). ${ }^{5}$

\section{THE KEY AGENCIES}

Early in 2020, a triad of UK regulators - the Competition and Markets Authority (CMA), Office of Communications (Ofcom) and the Information Commissioner's Office (ICO)began to dominate platform regulation. As anticipated, these agencies are now central to concurrent practice (Kretschmer et al., 2021).

The CMA is the UK competition regulator, a designated national authority that seeks to promote competition, both within and outside the United Kingdom, for the benefit of consumers. The CMA investigates mergers, conducts market studies and runs inquiries into anticompetitive behaviour. Its reach extends into digital markets, both directly and through its affiliated body, the Digital Markets Unit (DMU), discussed below. Under ERRA's provisions, the CMA - as the pivotal agency in the regulatory field - has increased its cooperation with concurrent regulators; it expected an 'increased merger and antitrust role' after Brexit (OECD, 2018, p. 4, 7).

Ofcom is the UK communications regulator, established by the Communications Act 2003. A converged body, Ofcom incorporated the work of five predecessors: the Broadcasting Standards Commission, the Independent Television Commission, the Office of Telecommunications, the Radio Authority and the Radiocommunications Agency. Ofcom regulates the TV, radio and video-on-demand sectors, fixed-line telecoms, mobile telephony, postal services and wireless spectrum. In April 2017, under the BBC's new Charter and Agreement, Ofcom became responsible for externally regulating the BBC's performance and editorial standards and the competitive impact of its services. Late in 2020, Ofcom was designated by the government as the 'online harms' regulator, once again extending its reach. 
The ICO is an independent public body, sponsored by the Department for Digital, Culture, Media and Sport (DCMS). The Information Commissioner, an official appointed by the Crown, is the UK's independent regulator for Data Protection and Freedom of Information, with key responsibilities under the Data Protection Act 2018 and the Freedom of Information Act 2000.

A further regulator has begun to assume a more central role. The Financial Conduct Authority (FCA) is a conduct regulator for some 51,000 financial services firms and financial markets in the United Kingdom and prudential supervisor of 49,000 firms. Its purpose is defined by the Financial Services and Markets Act 2000. The FCA aims to protect consumers and financial markets and promote competition. An independent public body, funded entirely by the firms it regulates, it is accountable both to the UK Treasury and Parliament.

\section{THE FURMAN REVIEW AND COMPETITION}

In late 2018, a ministerial working group on future regulation, chaired by Business Secretary Greg Clark, began meeting quarterly (BEIS, 2018). UK policy discussion was increasingly dominated by the challenge of regulating Facebook and Google (Andrews, 2020; Kretchmer et al., 2021; Moore \& Tambini, 2018).

BEIS and the Treasury set up the Digital Competition Expert Panel (DCEP) to review competition policy for digital markets. This is known as the Furman Review, after its chair, Harvard economist Jason Furman. Unlocking Digital Competition, published in March 2019, aligned with government and CMA thinking (DCEP, 2019). Furman advocated a 'procompetition' policy focused on consumer benefit, with 'rules to limit competitive actions by the most significant digital platforms while also reducing structural barriers that currently hinder effective competition' (DCEP, 2019, p. 2). As Mansell and Steinmueller (2020, p. 108) succinctly note, 'competition policy and antitrust provisions aim at ensuring that competition is fair and advances consumer welfare', which 'depends on determinations about effects within a construct called the "relevant market"'.

Furman's key recommendation was the creation of a well-resourced DMU linked to the CMA, Ofcom and the ICO (DCEP, 2019, pp. 10-11). ${ }^{6}$ Taking an ex ante approach, the DMU would develop enforceable 'codes of conduct' for firms with Strategic Market Status (SMS). SMS designation would follow an 'evidence-based assessment' identifying 'those firms with substantial and entrenched market power, in at least one digital activity, providing them with a strategic position'.

In the current debate about US and EU ex ante measures, designation criteria are a key focus (Schnitzer et al., 2021). In the United Kingdom, it is unclear what kind of economic power an SMS designation is meant to cover; there are also questions about how identification of an SMS firm might proceed. Moreover, as major digital firms operate across jurisdictions, how regulators in other countries define market power matters greatly for the United Kingdom, especially where cross-border collaboration is involved (Eben, 2021; Schnitzer et al., 2021).

Furman also proposed complementary merger and antitrust policies, hailing the opportunity for UK 'global leadership' in the regulatory field (DCEP, 2019, pp. 5-7, p. 50). With the transnational dimension in mind, the panel welcomed the government's intention to cooperate effectively with the EU as well as 'countries outside the EU, alongside other reciprocal arrangements' (DCEP, 2019, p. 123). 


\section{An emerging strategy}

By June 2019, Furman's conventional wisdom was part and parcel of the CMA's Digital Markets Strategy (CMA, 2019), which inter alia addressed machine learning, artificial intelligence and digital advertising. The key policy point, however, was to endorse Furman's DMU proposal (CMA, 2019, p. 11).

The CMA (2019, p. 6)-the focal agency of the UK Competition Network (Dunne, 2021, p. 260)—stated its commitment to 'regulatory concurrency' with cross-sector bodies (the ICO and Trading Standards) and sector-specific agencies (Ofcom and the FCA). It also stressed international collaboration with the European Competition Network, the OECD, International Competition Network, and International Consumer Protection and Enforcement Network.

The Strategy noted digital platforms' competitive challenges to UK journalism, citing the DCMS-commissioned Cairncross Review's (2019) analysis of the effects of search engines and news aggregation services on press publishers' loss of advertising revenue. Cairncross argued that major platforms' threat to sustainable quality journalism contributed to disinformation and declining public-interest reporting.

\section{From the review to the taskforce}

In March 2020, the government accepted Furman's strategic recommendations. It asked the CMA to establish a Digital Markets Taskforce (DMTF), which was joined by Ofcom and the ICO. The same month, the CMA's Annual Plan 2020/21 endorsed Furman's push for the 'development of a new pro-competition regulatory regime for digital platforms' (CMA, 2020a, p. 14). '[T]ackling concerns in digital markets' was a strategic objective because 'most markets are increasingly digital' (CMA, 2020a, p. 9, 13)-a neat statement of the rationale for a pro-competitive neo-regulatory order. The 'global nature' of digital markets required internationally 'concerted action' (CMA, 2020a, pp. 13-14): the 'colleges' supervising the largest global banks were cited as a relevant model (CMA, 2020a, p. 8).

On 1 July 2020, the CMA published Online Platforms and Digital Advertising, its final report on Google's overwhelming dominance of the UK search advertising market and Facebook's sway over the display advertising market. The two platforms jointly accounted for over a third of UK internet users' time online (CMA, 2020b, p. 5). The CMA's market investigation into digital advertising was postponed as the regulator decided its priority was to change the present regulatory regime, prompting Lovdahl Gormsen (2021, p. 384) to comment that 'a bolder, more confident and critical competition enforcer' was needed.

The CMA (2020b, p. 21) focused on making a 'compelling case for the development of a pro-competition ex ante regulatory regime to oversee the activities of online platforms funded by digital activity'. Following Furman, it advocated a DMU empowered to enforce a code of conduct on SMS platforms. The code's broad objectives would be fair trading, open choice, and trust and transparency, supplemented by detailed prescriptions (CMA, 2020b, p. 23). Concurrent collaboration with the ICO 'on issues relating to the intersection of competition and data protection law' would continue and, following Brexit, so would working 'closely with the European Commission' (CMA, 2020b, pp. 32-33, p. 436). 


\section{The government's view}

In November 2020, the Business and Culture departments responded to the CMA's report:

A new pro-competition regime will form a key part of our forthcoming Digital Strategy, where we will set out our overarching approach to regulating digital technology. [...] We will also set out the action we are taking to ensure the coherence of our approach, including streamlining the digital regulatory landscape, minimising overlaps and ensuring strong coordination between regulators (BEIS \& DMCS, 2020, p. 11).

The government endorsed both the Furman Review and the CMA's Market Study. An enforceable code of conduct applied to SMS platforms by a powerful, statutorilyunderpinned DMU was on the agenda. The Cairncross Review (2019) was supported: the press's loss of advertising, notably to Google and Facebook, required a code of conduct to govern commercial arrangements between news publishers and major platforms. The DMU (as a non-statutory body) would be located within the CMA from April 2021 onwards (CMA, 2021, p. 5).

Yet caution prevailed:

The Government agrees in principle with giving pro-competition powers to the DMU. However, these interventions are complex and come with significant policy and implementation risks. More work is required to understand the likely benefits, risks and possible unintended consequences of the range of proposed pro-competitive interventions (BEIS \& DCMS, 2020, p. 10).

A consultation on the DMU's powers closed on 1 October 2021. A report was still awaited at this time of writing.

\section{The DMTF}

Policy preferences were well established when, in March 2020, the CMA launched the DMTF to 'build on the outputs of the Furman Review, as well as drawing evidence from the CMA's market study into online platforms and digital advertising' (CMA, 2020c, p. 2). The Taskforce reported on 3 December 2020. During its deliberations, a new body called the Digital Regulation Cooperation Forum (DRCF)—discussed below-was set up.

Noting that "digital" is not a sector' (CMA, 2020c, p. 75), the Taskforce concluded that regulators needed to combine forces to address major platforms' power. Codes of conduct might include interventions regarding 'personal data mobility, interoperability and data access [...] to address the factors which are the source of an SMS firm's market power in a particular activity' (CMA, 2020c, p. 13).

The report recommended that the DMU operate as a 'centre of expertise for digital markets' focused on the SMS regime, with 'primacy' in designating SMS assessments in the digital economy (CMA, 2020c, p. 3). It would collaborate with Ofcom in respect of 'online harms', the ICO regarding data and privacy, and the FCA in regulating financial services (CMA, 2020c, p. 75). The CMA would handle mergers.

The Taskforce emphasised the need for regulatory collaboration. Within the United Kingdom, that meant supporting the new DRCF, while using the 'college' model internationally (CMA, 2020c, pp. 78-80). It was now imperative, it argued, to put both regulators' collaboration and the DMU on a statutory footing, and also make a soft power gain: 
We urge government to move quickly in taking this legislation forward. As government rightly acknowledges, similar action is being pursued across the globe and there is a clear opportunity for the UK to lead the way in championing a modern pro-competition, pro-innovation regime (CMA, 2020c, p. 81).

\section{THE DRCF}

A brief press release, issued on 1 July 2020 by the CMA, Ofcom and the ICO, announced the creation of the DRCF. The three bodies had combined forces to achieve coherent, informed and responsive regulation of the UK digital economy which serves citizens and consumers and enhances the global impact and position of the UK' (DRCF, 2020, p. 1). Regulators' disparate remits remained, despite formal collaboration, therefore the DRCF was 'a non-statutory body [...] not a decision-making body'; it would 'not provide formal advice or direction to members' (DRCF, 2020, p. 2).

The previous year, the House of Lords Communications Committee (2019, pp. 62-66) had criticised the fragmented regulatory landscape and the slowness of the legislative response to rapid change. It recommended setting up a Digital Authority with oversight of all relevant regulators and, indeed, should be credited with initiating the idea of a wide-ranging neo-regulatory regime in the United Kingdom, although that was not the terminology used. The DRCF's founding statement made no allusion to this proposal but was clearly intended as a riposte.

\section{Speaking with one voice?}

The DRCF's Plan of Work 2021/22, published on 10 March 2021, identified three benefits of concurrency: (1) providing coherent digital regulation in the public interest; (2) responding strategically to industrial and technological developments; (3) building shared skills and capabilities 'to develop and make use of shared resources' (DRCF, 2021a, p. 3). ${ }^{7}$

Regulation had to keep pace with firms' development and technological innovation. Seeking 'coherence across digital and traditional services' was a must, faced with disinformation and misinformation, as well as the concentrations of monopoly power 'restraining growth, holding back innovation' (DRCF, 2021a, p. 2). Burnishing its soft power credentials, the DRCF described itself as 'the first national regulatory network [...] for regulating digital services' (DRCF, 2021a, p. 3). ${ }^{8}$

The DRCF's creation has been a strategic, neo-regulatory response to the complex, dynamic and wide-ranging international challenges of platform regulation. It has stressed the need to become a one-stop-shop where 'joint project teams share resources and expertise, engage once with stakeholders rather than separately, and publish our findings jointly' (DRCF, 2021a, p. 4). Kate Davies (2021), Ofcom Public Policy Director, however, has recognised the DRCF's present limitations: the 'workplan signals a true shift in regulatory coordination' but, she conceded, 'what it means to engage as a cross-regulatory forum is still a little untested'.

\section{Further capacity building}

In May 2021, the DRCF published its clarion call for structural reform. Responding to the DCMS, ${ }^{9}$ it proclaimed its novelty: 'Our ambitions for the DRCF represent a true innovation in 
the breadth and depth of cooperation between regulators.' In November 2020, the government asked what further measures might deliver 'effective digital regulation'. The DRCF responded that collaboration would 'help us provide policy coherence in the public interest, respond strategically to industry and technological developments, and build skills and capacities'. However, there was a 'need to develop a legislative framework that embeds cooperation in the digital regulatory landscape' (DRCF, 2021b, p. 1).

The government was asked 'to incorporate regulatory coherence and cooperation into the duties of digital regulators', with the adoption of a common principle to 'promote the interests of consumers and citizens', with duties to consult and cooperate, as under financial sector regulators' legislation (DRCF, 2021b, p. 5, 7). ${ }^{10}$ Data- and information-sharing were needed for 'cross-cutting work' (DRCF, 2021b, p. 2). ${ }^{11}$ The government was asked to clarify 'the desirable scope of digital regulatory cooperation' (DRCF, 2021b, pp. 9-10).

The DRCF now considered its expertise, resources and stakeholder connections had trumped the case for a new Digital Authority on the grounds that this would complicate coordination, might duplicate scarce resources, and might also obscure how regulators' roles are to be understood by industry and consumers (DRCF, 2021b, p. 10). In written evidence to the House of Lords Communications and Digital Committee's Inquiry into Digital Regulation, reiterating its stance, the DRCF argued that it could 'deliver the same benefits without the need for introducing additional authority' (DRCF, 2021c). In November 2021, the forum model was reinforced by Gill Whitehead's appointment as DRCF Chief Executive in 'charge of the Secretariat formed by each of the regulators', collaborating with their CEOs 'to ensure that regulatory policy is developed in a responsive and holistic way'. Whitehead was formerly a member of Google's UK Management Group, her employer since 2016, where she had led 'specialist teams in data science, analytics, measurement and UX' (Ofcom, 2021b). This appointment did not have parliamentary scrutiny and highlighted the forum's unaccountable status. It was rapidly followed by a shot across the DRCF's bows.

In mid-December 2021, in the most focused British parliamentary analysis of the state of digital regulation to date, the House of Lords Communications and Digital Committee (2021b, p. 2) considered the establishment of the DRCF to be a 'small step in the right direction'. It was sharply critical of 'a lack of overarching coordination and oversight of regulatory objectives'. The Committee (2021b, p. 21) recommended that the DRCF be put on a statutory footing, with 'the power to resolve conflicts by directing its members'. It agreed with the DRCF that statutory duties be imposed on regulators 'to cooperate and consult with each other, allowing them to share their powers and jointly regulate'. The spectre of the Digital Authority returned in the recommendation that the DRCF be renamed the 'Digital Regulation Board', with an independent nonexecutive chair and members. Parliamentary scrutiny was recommended by setting up a Joint Committee on Digital Regulation to consider regulators' exercise of their powers and the coherence of their work. It would also be asked to scrutinise the government's cross-departmental digital work.

Evidence cited in the Lords Committee's report showed that a turf-war had begun. The stakes concerned which regulatory bodies, specialist interests, academics and other researchers should have a seat at the regulatory table. From its somewhat subterranean, voluntary origins, the increased public prominence of the DRCF in 2021 had proved catalytic, capable of mobilising diverse interests while raising the intensity of parliamentary scrutiny. Although still an expert's game, a wider debate had begun about how best to mobilise a wide range of relevant know-how regarding the transformative changes underway in the digital sphere. Forum-style collaboration might have forestalled the creation of a Digital Authority. However, the present model's efficacy will be intensely scrutinised by its critics, and the DRCF will also face increased clamour by those who seek admittance to the club. 
The House of Lords Communications and Digital Committee's recommendations were endorsed by the House of Lords and House of Commons Joint Committee on the Draft Online Safety Bill (2021, pp. 151-53, p. 157). Parliamentary scrutiny at the close of 2021 put digital neo-regulation on the public agenda and raised questions about its future organisational shape.

\section{TOWARDS 'ONLINE SAFETY'}

The pro-competition agenda, dominated by the CMA, has been the fulcrum of neoregulatory developments. However, official and public attention have focused overwhelmingly on 'online harms', Ofcom's province. Established as a 'peak' institution in 2003, Ofcom was part of 'the trend towards the creation of regulatory agencies designed to provide synoptic overviews of wide social domains' (Moran, 2004, p. 146). Such 'converged' design contrasts sharply with the DRCF's lateral, incremental approach to regulatory consolidation.

Ofcom's (2018) agenda-setting discussion paper, Addressing harmful online content, laid claim to an expanded remit, its checklist including activities harmful to children, spreading terrorist content, incitement to violence and misinformation. In April 2019, Ofcom's initiative was followed by the government's Online Harms White Paper, on which a consultation ensued (DCMS \& Home Office, 2020). Finally, on 15 December 2020, the government designated Ofcom as an online harms regulator. Published on 12 May 2021, the Draft Online Safety Bill's 'Explanatory Notes' described Ofcom's core role as overseeing and enforcing 'the new regulatory regime (including dedicated powers in relation to terrorism content and child sexual exploitation and abuse content)' as well as preparing 'codes of practice to assist providers in complying with their duties of care' (Draft Online Safety Bill, 2021 p. 4).

Between September and November 2021, the parliamentary Joint Committee took wideranging evidence on the Draft Online Safety Bill. Its report was published on 14 December 2021 (House of Lords House of Commons, 2021).

\section{POST-BREXIT INTIMATIONS}

Post-Brexit, the United Kingdom has ceased to legislate in line with the EU's e-Commerce Directive, the fundamental legal framework for online services in the Single Market (Draft Online Safety Bill, 2021, p. 7). Regulatory divergence from the EU has been specifically signalled in two key policy fields.

\section{Whither net neutrality?}

On 7 September 2021, Ofcom (2020, p. 3) called for evidence for its review of net neutrality, which it described as 'ensuring that users of the internet can control what they see and do online-not the internet service provider that connects them to the internet'.

Ofcom no longer had to take 'utmost account' of Open Internet guidelines issued by the Body of European Regulators for Electronic Communications (BEREC). A pro-competition rationale set the stage for its review:

[I]t is important that the net neutrality framework continues to best serve citizen and consumer interests and promote access and choice, while also supporting innovation and investment in the digital space (Ofcom, 2021a, p. 9). 
Net neutrality has long been a prime focus of debate over the nature of 'internet freedom' (Tambini, 2021), and is also central to the defence of non-discriminatory transmission of data over the internet, whether for reasons of network efficiency or 'facilitation of permissionless innovation' (O'Hara \& Hall, 2021, p. 57). For some, net neutrality underpinned by the EU's Open Internet Regulation 2015/2120 constitutes a barrier to innovation in 5G services (Frias \& Martínez, 2017), although the EU maintains that, for instance, network slicing, 5QI and Mobile Edge Computing are not impeded by its rules (BEREC 2021a, 2021b). That debate continues. At this time of writing, the outcome of Ofcom's review is unknown.

\section{Reforming the data economy}

O'Hara and Hall (2021, p. 239) observe that control over data 'brings power' and hence a 'rationale for data nationalism'. Pertinently, on 21 August 2021, the DCMS (2021) announced its 'post-Brexit global data plans'. ${ }^{12}$ Digital Secretary Oliver Dowden stressed that the United Kingdom could now develop 'a world-leading data policy [...] seeking new international data partnerships [...] reforming our own data laws', with the ICO engendering 'a new era of data-driven growth and innovation'. The regulator would now 'encourage the responsible use of data to achieve economic and social goals as well as preventing privacy breaches', in line with the government's wish to remove barriers to data flows, although apparently it is intended to 'maintain equivalence with the EU's data standards [...] while developing a new pro-growth approach to data law' (DCMS, 2021)..$^{13}$

It remains to be seen how this data trade policy will square with national security concerns, which remain a live issue. In November 2021, the geopolitical significance of data and connectivity were underlined by Richard Moore (2021, p. 2), Chief of the UK Secret Intelligence Service (MI6), with Chinese cyber warfare a particular concern.

\section{CONCLUSION}

Almost two decades ago, Moran (2004) anatomised 'hyper-innovation' in the British regulatory state. As has been shown, from March 2020 to July 2021, while the Covid-19 pandemic held much of the United Kingdom on pause, key steps were taken towards establishing a neo-regulatory platform regime. Hyper-innovation is evidently alive and well.

Brexit has been a geopolitical spur for the process depicted here. In its architects' vision of a sovereign national security state, regulation is seen as key to the defence of the realm, with cyber-space a prime battleground. Similarly, economic competitiveness is an overarching government priority, hence its enthusiasm for the pro-competition approach driving the CMA, which is also evident in Ofcom's review of net neutrality and the ICO's mission to reform the data economy. The global-British path is meant to be distinctive. But the more the United Kingdom diverges from the EU Single Market, the less can it rely on its previous regulatory equivalence with the world's largest trading bloc.

The United Kingdom is now in the early stages of establishing a neo-regulatory regime, in which key regulators have coalesced to rationalise a patchwork quilt of statutory powers. So far, the vogue for agile regulation has reinforced the DRCF's concurrent approach, resulting in an incremental deepening of inter-regulator relations. The new framework has been driven by an ambition to match major platforms' reach. Much will depend on the effectiveness of the codes of practice and of conduct that figure large in addressing online harms and promoting a pro-competition policy. The DRCF model is cumbersome, requiring continual adjustment as it extends its membership. The appointment of a coordinating CEO and secretariat has ensured the forum's increased visibility. The DRCF's evolution, 
membership, governance and effectiveness will encounter increasingly robust parliamentary scrutiny and wider debate. Whether a Digital Regulation Board is in the offing is a matter of conjecture. It is likely, though, that pressures to change the form and functioning of the DRCF will intensify.

Two legislative keystones are pending. The Online Safety Bill will be enacted in 2022, whereas pro-competition legislation regarding the DMU is also anticipated. Beyond the United Kingdom, will 'the benefits of concurrent enforcement' (Dunne, 2021, p. 281) arouse international interest? British platform regulation's global reputation will depend on its achieving coherence and demonstrable efficacy. At that point, its wider appeal and potential transferability to other jurisdictions might realistically be considered.

\section{CONFLICT OF INTERESTS}

The authors declare that there are no conflict of interests.

\section{ORCID}

\section{Philip Schlesinger (10) http://orcid.org/0000-0003-0078-9630}

\section{ENDNOTES}

${ }^{1}$ Along with Canada, Denmark, Italy, Japan, Singapore and the UAE.

${ }^{2}$ For parliamentary criticism, see House of Commons and House of Lords (2021) and House of Lords (2021a).

${ }^{3}$ Arguably, UK China policy's 'deliberate ambiguity' shifts between pursuing economic interests and upholding democratic values. See House of Lords (2021a, p. 92).

4 The Intelligence and Security Committee of Parliament's (2020) redacted report, Russia—publication delayed by the Johnson government-concluded that the United Kingdom remains open to Russian state penetration.

5 The WEF (2020, p. 9) identified this body as an example of 'anticipatory regulation'.

${ }^{6}$ Furman hinted at the DMU's eventual location: 'Definition of scope would be less important if the unit sat within the CMA, with its economy-wide scope' (DCEP, 2019, p. 80, footnote 18).

7 Following a year's observer status, the FCA joined the DRCF on 1 April 2021 but did not contribute to the May 2021 review.

${ }^{8}$ A brief footnote compared parallel moves in the United States, the EU and Australia.

9 This addressed reservations in the government's response to the CMA's Market Study, cited above.

10 Specific articles of the Financial Services and Markets Act 2000 refer, as noted on p. 8 of the DRCF's Plan.

11 Legal frameworks and obstacles to information exchange are noted on p. 4 of the DRCF's Plan.

12 These included appointing a new Information Commissioner (John Edwards, New Zealand's former Privacy Commissioner) to head the ICO.

${ }^{13}$ Data equivalence may hang on the UK and the EU resolving outstanding disputes under their Trade and Cooperation Agreement.

\section{REFERENCES}

Andrews, L. (2020). Facebook, the media and democracy: Big tech, small state?. Routledge.

BEIS (2018, October 24). Business Secretary hosts first cross-government working group on future regulation [BEIS Press Release]. https://www.gov.uk/government/news/business-secretary-hosts-first-cross-government-workinggroup-on-future-regulation

BEIS. (2019). Regulatory policy committee. https://www.gov.uk/government/organisations/regulatory-policy-committee

BEIS (2020, March). Better regulation framework: Interim guidance. https://assets.publishing.service.gov.uk/ government/uploads/system/uploads/attachment_data/file/916918/better-regulation-guidance.pdf

BEIS \& DCMS (2020, November). Response to the CMA's market study into online platforms and digital advertising. https://assets.publishing.service.gov.uk/government/uploads/system/uploads/attachment_data/file/ 939008/government-response-to-cma-study.pdf 
BEREC. (2021a). All you need to know about the Open Internet rules in the EU. https://berec.europa.eu/eng/open_ internet/

BEREC. (2021b). 5G. https://berec.europa.eu/eng/open_internet/5g/

Cabinet Office (2017, January). Regulatory futures review. Policy Paper. https://assets.publishing.service.gov.uk/ government/uploads/system/uploads/attachment_data/file/582283/Regulatory_Futures_Review.pdf

Cairncross Review. (2019, February 12). A sustainable future for journalism. Department for Digital Culture, Media and Sport. https://assets.publishing.service.gov.uk/government/uploads/system/uploads/attachment_data/ file/779882/021919_DCMS_Cairncross_Review_.pdf

CEBS. (2010). Guidelines for the operational functioning of supervisory colleges (GL34). Committee of European Banking Supervisors. 15 June. https:/www.eba.europa.eu/regulation-and-policy/colleges-of-supervisors/ guidelines-for-the-operational-functioning-of-colleges

CMA (2019, July). The CMA's digital markets strategy. https://assets.publishing.service.gov.uk/government/ uploads/system/uploads/attachment_data/file/814709/cma_digital_strategy_2019.pdf

CMA (2020a, March). Competition and markets authority annual plan 2020/21 (CMA 112). https://assets. publishing.service.gov.uk/government/uploads/system/uploads/attachment_data/file/873689/Annual_Plan_ 2020-21.pdf

CMA (2020b, July 1). Online platforms and digital advertising: Market study final report. https://assets.publishing. service.gov.uk/media/5fa557668fa8f5788db46efc/Final_report_Digital_ALT_TEXT.pdf

CMA (2020c, December). A new pro-competition regime for digital markets: Advice of the digital markets task force (CMA 135). https://assets.publishing.service.gov.uk/media/5fce7567e90e07562f98286c/Digital_Taskforce_-_ Advice.pdf

CMA (2021, February 2021 Refresh). The CMA's digital markets strategy. https://www.gov.uk/government/ publications/competition-and-markets-authoritys-digital-markets-strategy/the-cmas-digital-markets-strategyfebruary-2021-refresh

Davies, K. (2021, November 10). The digital regulation forum: Working for greater cooperation in regulating online platforms. https://www.ofcom.org.uk/news-centre/2021/working-for-greater-cooperation-in-online-regulation

Digital Competition Expert Panel (DCEP). (2019). Unlocking digital competition. HM Treasury and BEIS. https:// www.gov.uk/government/publications/unlocking-digital-competition-report-of-the-digital-competition-expertpanel

DCMS. (2021, August 26). UK unveils post-Brexit global data plans to boost growth, increase trade and improve healthcare [Press Release]. https://www.gov.uk/government/news/uk-unveils-post-brexit-global-data-plansto-boost-growth-increase-trade-and-improve-healthcare

DCMS and Home Office. (2020). Full government response to the consultation online harms [White Paper]. Command Paper 354. https://www.gov.uk/government/consultations/online-harms-white-paper/outcome/ online-harms-white-paper-full-government-response\#executive-summary

Draft Online Safety Bill (2021, May). Presented to Parliament by the Minister of State for Digital by Command of Her Majesty. https://assets.publishing.service.gov.uk/government/uploads/system/uploads/attachment_data/ file/985033/Draft_Online_Safety_Bill_Bookmarked.pdf

DRCF (2020, July 1). Digital regulation cooperation forum [Press Release]. CMA, ICO and Ofcom. https://www. gov.uk/government/collections/the-digital-regulation-cooperation-forum

DRCF. (2021a, March 10). Plan of work 2021/22. CMA, ICO and Ofcom. https://www.gov.uk/government/ publications/digital-regulation-cooperation-forum-workplan-202122/digital-regulation-cooperation-forum-planof-work-for-2021-to-2022

DRCF (2021b, May). Digital regulation cooperation forum. Embedding coherence and cooperation in the fabric of digital regulators. CMA, Ofcom and ICO. https://assets.publishing.service.gov.uk/government/uploads/ system/uploads/attachment_data/file/982898/DRCF_response_to_DCMS_PDF.pdf

DRCF (2021c). Digital Regulation Cooperation Forum - Written evidence (DRG0019). House of Lords Communications and Digital Committee Inquiry into Digital Regulation. https://www.ofcom.org.uk/_data/assets/pdf_ file/0022/228064/drcf-response-digital-regulation-inquiry.pdf

Dunne, N. (2021). Concurrency. In B. Rodger, P. Whelan, \& A. McCulloch (Eds.), The UK competition regime: $A$ twenty-year retrospective (pp. 255-281). Oxford Scholarship Online.

Eben, M. (2021). The interpretation of a 'Strategic Market Status': A response to the public consultation by the UK Government on 'A new pro-competition regime for digital markets' (Working Paper 2021/10). CREATe, University of Glasgow. https://zenodo.org/record/5575183\#.YgwD1i-l3dd

eSafety Commissioner. (2021, July). Online Safety Act 2021 [Fact Sheet]. https://www.esafety.gov.au/sites/default/ files/2021-07/Online\%20Safety\%20Act\%20-\%20Fact\%20sheet.pdf

European Commission. (2021a). The digital markets act: Ensuring fair and open digital markets. https://ec.europa. eu/info/strategy/priorities-2019-2024/europe-fit-digital-age/digital-markets-act-ensuring-fair-and-open-digitalmarkets_en 
European Commission. (2021b). Europe fit for the digital age: New online rules for platforms. https://ec.europa.eu/ info/strategy/priorities-2019-2024/europe-fit-digital-age/digital-services-act-ensuring-safe-and-accountableonline-environment/europe-fit-digital-age-new-online-rules-platforms_en

Faroohar, R. (2018). Techlash. Financial Times. https://:www.ft.com/content/76578fba-fca-11e8-ac00-57a2a82643e

Financial Services Regulator Initiatives Forum. (2021, May). Regulatory initiatives grid. https://www.fca.org.uk/ publications/corporate-documents/regulatory-initiatives-grid

Flew, T. (2021). Regulating platforms. Polity Press.

Frias, Z., \& Martínez, J. P. (2017). 5G networks: Will technology and policy collide? Telecommunications Policy, 42(8), 612-621.

FSA. (2009, March). Turner review. A regulatory response to the global banking crisis. https:/www.actuaries.org/ CTTEES_TFRISKCRISIS/Documents/turner_review.pdf

Hancher, L., \& Moran, M. (1998). Organizing regulatory space. In R. Baldwin, C. Scott, \& C. Hood (Eds.), A reader on regulation (pp. 148-172). Oxford University Press. https://doi.org/10.1093/acprof:oso/9780198765295. 003.0005

HM Government. (2019, June). Regulation for the Fourth Industrial Revolution [White Paper, CP111]. https://assets. publishing.service.gov.uk/government/uploads/system/uploads/attachment_data/file/807805/regulation-fourthindustrial-strategy-white-paper-print.pdf

HM Government. (2020, November 25). Agile nations charter. https://assets.publishing.service.gov.uk/ government/uploads/system/uploads/attachment_data/file/942312/Agile_Nations_Charter.pdf

HM Government (2021, March). Global Britain in a competitive age: The integrated review of security, defence, development and foreign policy (CP 403). https://www.gov.uk/government/publications/global-britain-in-acompetitive-age-the-integrated-review-of-security-defence-development-and-foreign-policy

House of Lords. (2019, March 9). Select Committee on Communications. Regulating in a digital world. https:// publications. parliament.uk/pa/ld201719/ldselect/ldcomuni/299/299.pdf

House of Lords (2021a, September 10). The UK and China's security and trade relationship: A strategic void (HL Paper 62). International Relations and Defence Committee. https://publications.parliament.uk/pa/ld5802/ Idselect/ldintrel/62/62.pdf

House of Lords (2021b, December 13). Communications and Digital Committee. Digital regulation: Joined up and accountable (HL Paper 126). https://committees.parliament.uk/publications/8186/documents/83794/default/

House of Lords, House of Commons. (2021, December 14). Joint Committee. Draft Online Safety Bill (HL Paper 129, HC 609). https://committees.parliament.uk/publications/8206/documents/84092/default/

Intelligence and Security Committee of Parliament (2020, July 21). Russia (HC632). https://isc.independent.gov.uk/ wp-content/uploads/2021/03/CCS207_CCS0221966010-001_Russia-Report-v02-Web_Accessible.pdf

Khan, L. M. (2018). Amazon—an infrastructure service and its challenge to current antitrust law. Digital dominance: The power of Google, Amazon, Facebook, and Apple (98-129). Oxford University Press.

Kretschmer, M., Furgal, U. \& Schlesinger, P. (2021). The emergence of platform regulation in the UK: An empiricallegal study (Discussion Paper 2021/06). Creative Industries Policy \& Evidence Centre. https://www.pec.ac.uk/ discussion-papers/the-emergence-of-platform-regulation-in-the-uk

Lovdahl Gormsen, L. (2021). Competition law and the digital economy in the UK and beyond. In B. Rodger, P. Whelan, \& A. McCulloch (Eds.), The UK competition regime: A twenty-year retrospective (pp. 359-387). Oxford Scholarship Online.

Mansell, R., \& Steinmueller, W. E. (2020). Advanced introduction to platform economics. Edward Elgar.

Moore, R. 2021. Speech by SIS chief Richard Moore: Human intelligence in the digital age. https://www.sis.gov. uk/richard-moore-first-public-speech.html

Moore, M. \& Tambini, D. D. (2018). Digital dominance: The power of Google, Amazon, Facebook, and Apple. Oxford University Press.

Moran, M. (2004). The british regulatory state: High modernism and hyper-innovation. Oxford University Press.

Mueller, M. (2017). Will the internet fragment? sovereignty, globalization, and cyberspace. Polity Press.

National Cyber Security Centre. (2020, January). Security analysis for the UK Telecoms sector. Summary of Findings.

Nye Jr., J. S. (1990). Soft power. Foreign Policy, 80(Autumn), 153-171.

OECD (2018, October 31). Annual report on competition policy developments in the United Kingdom (DAF/ COMPIAR(2018)48). Directorate for Financial and Enterprise Affairs, Competition Committee. https://www. oecd.org/officialdocuments/publicdisplaydocumentpdf/?cote=DAF/COMP/AR(2018)48\&docLanguage=En

OECD. (2021a). OECD regulatory policy outlook 2021. https://www.oecd.org/gov/regulatory-policy/oecdregulatory-policy-outlook-2021-38b0fdb1-en.htm

OECD. (2021b, July 20). Practical guidance on agile regulatory governance to harness innovation. https:// legalinstruments.oecd.org/public/doc/669/51f6da97-c198-4c93-922f-1a5d80beae86. pdf 
OECDg. (2021c). Recommendation of the council for agile regulatory governance to harness innovation (OECD/ LEGAL/0464). https://www.oecd.org/mcm/Recommendation-for-Agile-Regulatory-Governance-to-HarnessInnovation.pdf

Ofcom (2018, September 18). Addressing harmful online content: a perspective from broadcasting and ondemand standards regulation. https://www.ofcom.org.uk/_data/assets/pdf_file/0022/120991/Addressingharmful-online-content.pdf

Ofcom (2020, December 15). Ofcom to regulate harmful content online [Press Release]. https://www.ofcom.org.uk/ about-ofcom/latest/features-and-news/ofcom-to-regulate-harmful-content-online

Ofcom. (2021a, September 7). Net neutrality review. Call for evidence. https://www.ofcom.org.uk/consultationsand-statements/category-2/call-for-evidence-net-neutrality-review

Ofcom. (2021b, November 1). Gill Whitehead appointed Chief Executive of Digital Regulators Forum. https://www. ofcom.org.uk/news-centre/2021/gill-whitehead-appointed-digital-regulators-forum-chief-executive

O'Hara, K., \& Hall, W. (2021). Four internets: Data, geopolitics, and the governance of cyberspace. Oxford University Press.

Schnitzer, M., Crémer, J., Dinielli, D., Fletcher, A., Heidhues, P., Scott Morton, F. \& Seim, K. (2021). International coherence in digital platform regulation: An economic perspective on the US and EU proposals (Policy Discussion Paper No. 5). Digital Regulation Project, Yale Tobin Center for Economic Policy. https://tobin.yale. edu/sites/default/files/pdfs/digital\%20regulation\%20papers/Digital\%20Regulation\%20Project\%20-\%20Search\% 20-\%20Discussion\%20Paper\%20No\%202\%20(1).pdf

Stigler Committee on Digital Platforms (2019). Final report. Stigler Center, Chicago University. https://www. chicagobooth.edu/research/stigler/news-and-media/committee-on-digital-platforms-final-report

Tambini, D. (2021). Media Freedom. Polity Press.

WEF. (2018). Agile governance: Reimagining policy-making in the fourth industrial revolution. White Paper. https://www. weforum.org/whitepapers/agile-governance-reimagining-policy-making-in-the-fourth-industrial-revolution

WEF (2020). Agile regulation for the fourth industrial revolution: A toolkit for regulators. World Economic Forum. https://www.weforum.org/about/agile-regulation-for-the-fourth-industrial-revolution-a-toolkit-for-regulators

How to cite this article: Schlesinger, P. (2022). The neo-regulation of Internet platforms in the United Kingdom. Policy \& Internet, 14, 47-62.

https://doi.org/10.1002/poi3.288 